\title{
Screening of Ethanolic Extract of Borassus flabellifer Flowers for its Antidiabetic and Antioxidant Potential
}

\author{
Satish A. Kavatagimath ${ }^{1}$,Sunil S. Jalalpure ${ }^{2^{*}}$, Ravindra D. Hiremath ${ }^{2}$ \\ 'Department of Pharmaceutical Biotechnology, K. L. E. University College of Pharmacy, \\ Nehrunagar, Belagavi-590010, Karnataka, India \\ ${ }^{2}$ Department of Pharmacognosy and Phytochemistry, K. L. E. University College of Pharmacy \\ and Dr. Prabhakar Kore Basic Science Research Center, K. L. E. University, \\ Belagavi-590010, Karnataka, India; jalalpuresunil@rediffmail.com
}

\begin{abstract}
Diabetes mellitus is an age old metabolic disorder characterized by increased blood glucose levels. This may be due to deficiency of insulin (Type I Diabetes) or insulin resistance (Type II Diabetes). Traditional system of medicine provides with many plant sources for the effective management of diabetes mellitus preferable than any other system of medicine. The rationale behind use of such herbal medicines is to be supported by establishing the scientific basis for their traditional claims. In the present study ethanolic extract of Borassus flabellifer flowers was screened for its antidiabetic potential against alloxan induced diabetic rats. Oral Glucose Tolerance Test (OGTT), blood glucose level, serum lipid profile and histological study of pancreas were performed. The free radical scavenging effect was studied by using DPPH method. After administration of the ethanolic extract, there was a significant reduction in fasting blood glucose levels from $60 \mathrm{~min}$ (OGTT) acute study reveals blood glucose lowering potential of $20 \%$ at $6 \mathrm{hr}$ whereas sub-acute study after 15 days of treatment it was observed to be $35 \%$. The extract exerts a significant DPPH radical scavenging effect. From the data it can be inferred that ethanolic extract of Borassus flabellifer flowers are in confirmation with the claims made in traditional system of medicine. This marked antihyperglycemic effect and in vitro antioxidant potential may be attributed to the presence of active constituent's like flavonoids and triterpenoids.
\end{abstract}

Keywords: Anti-diabetic activity, antioxidant activity, Borassus flabellifer, flavonoids, triterpenoids

\section{Introduction}

Diabetes mellitus (DM) presently is a major health problem for the people and is a chronic metabolic disorder resulting from a variable interaction of hereditary and environmental factors, food habits, lifestyle and stress ${ }^{1}$. Number of people suffering from the disease worldwide is increasing at an alarming rate with a projected 366 million peoples by the year
2030 as against 191 million estimated in 2000. From literature review it has been revealed that $15-20 \%$ of diabetic patients are suffering from Insulin-Dependent Diabetes Mellitus (IDDM) or type- $\mathrm{I}^{1}$. Diabetes mellitus $(\mathrm{DM})$ is a chronic, complicated metabolic disorder characterized by either deficient insulin secretion by pancreatic $\beta$ cells or resistance to insulin. Another major contributing factor is believed to be the oxidative stress in the pathogenesis of diabetes. Glucose oxidation as

\footnotetext{
*Author for correspondence

Email: jalalpuresunil@rediffmail.com
} 
well as nonenzymatic protein glycosylation in diabetes itself leads to the increased production of Reactive Oxygen Species (ROS) ${ }^{2}$. Vascular abnormalities such as constriction and dilation of blood vessels were observed in diabetic patients. These complications further lead alterations in blood flow and peripheral vascular resistance resulting in cardiovascular disease, diabetic retinopathy, nephropathy, neuropathy and hypertension ${ }^{3}$. Nitric oxide (NO) is a potent vasodilator plays a major role in controlling of vascular homeostatis, among various other biologically active molecules. End point of diabetes in hyperglycemia, which is responsible for increased production of ROS such as DPPH and superoxide anion. These free radicals in turn deceases the bioavailability of nitric oxide ${ }^{4}$. Antioxidants have shown to prevent the destruction of $ß$ - cells by inhibiting the peroxidation chain reaction and it may provide protection against the development of diabetes ${ }^{5}$.

Herbal drugs believed to increase insulin secretion, enhance glucose uptake by adipose or muscle tissues and inhibit absorption as well as production of glucose from intestinal mucosa and liver respectively ${ }^{6}$. Several plant species are recommended for the effective management of diabetes in traditional system of medicines. A scientific rational approach with the standardization of these plants and plant sources is the need of the hour for development and validation of more effective therapeutic agents.

Borassus flabellifer L (Family-Arecaceae) is a tall and erect palm, with large, fan-shaped leaves ${ }^{7}$, commonly known as Palmyra palm or Asian toddy palm ${ }^{8}$. Different plant parts are used in the treatment of syphilis, heart burns, liver and spleen enlargement etc ${ }^{7}$. The flowers exert anti-inflammatory activity whereas bloom on base of leaves used as styptic for external wounds. Juice from flowering stalk of the plant is used in the management of diabetes. The plant has also been used for treatment of gonorrhea and respiratory ailments, leaf juice used for hiccups, gastric ailments, ulcers and abscesses $^{8}$. Fresh pulp is reportedly rich in vitamins A and $C$ whereas fresh sap is a good source of vitamin B-complex ${ }^{9}$.

Phytochemical investigation revealed the presence of gums, albuminoids, fats, saponins, carbohydrates like sucrose. Methanolic extract of roots and leaves shows the presence of flavonoids, saponins, tannins and phenolic compounds. The ethanolic extract of roots and leaves shows antioxidant activity ${ }^{7}$ whereas a significant antibacterial activity $^{10}$ was observed in methanolic extract of seed coat. Ethanolic extract of flower showed dose dependent and significant anti-inflammatory activity $^{11}$. In case of management of diabetes the fresh juice of flowering stalks is preferred ${ }^{12}$. The data reported suggests that the plant contains the chemical constituents which have shown anti-diabetic and antioxidant activity. Also the antioxidant activity supports it use in the management of diabetes. The present study intends to screen the ethanolic extract of Borassus flabellifer flower for anti-diabetic and antioxidant activity. This may further yield some more useful information to validate the claims made, as well as for the effective treatment of diabetes.

\section{Materials and Methods}

\subsection{Animals}

Swiss albino mice of either sex (20-25 gm weight), and healthy adult male Wister albino rats (170-200 gm) were used for acute toxicity study and anti-diabetic activity respectively. The animals were randomly divided in four groups $(n=6)$ and kept in clean cages. The animals were having free access to commercial rat chaw and water ad libitum. Temperature was maintained at $25^{\circ} \mathrm{C} \pm 2^{\circ} \mathrm{Cwith}$ $12 \mathrm{hr}$ day and night cycle. For the study institutional ethical clearance was obtained by Institutional Animal Ethics Committee (Vide: JNMC/IAEC/Res-2/9/2008 dated $19^{\text {th }}$ December 2008).

\subsection{Chemicals}

Glibenclamide was procured from Hoechst India Ltd. All chemicals and solvents used were of analytical grade.

\subsection{Collection of Plant Material}

The flowers of Borassus flabellifer were collected from surrounding areas of Belagavi districts, Karnataka, India. The specimen was authenticated from Prof. R. S. Goudar, Dept. of Botany, KLES's R. L. Science Institute, Belagavi, Karnataka, India. The herbaria are prepared and stored at Department of Pharmacognosy, K.L.E.University College of Pharmacy, Belagavi, (Karnataka) India. 


\subsection{Preparation of Plant Extract}

Flowers of Borassus flabellifer were shade dried at room temperature. The complete shed dried flowers were ground to coarse powder and passed through sieve no. 40 . This facilitates more effective extraction. Thus prepared powder was stored in a well closed glass jar for further studies. Cold maceration and continuous hot extraction (Soxhlet apparatus) method was adopted for extraction using $95 \%$ ethanol. The extracts were concentrated under reduced pressure using rotary evaporator (IKA 10) at $40^{\circ}$ $\mathrm{C}$ to yield a syrupy mass. For further investigations and evaluations the syrupy mass was stored in amber colored glass jar in refrigerator at $2-8^{\circ} \mathrm{C}$.

\subsection{Preliminary Phytochemical Investigations}

Preliminary phytochemical investigation revealed the presence of carbohydrates, steroids flavonoids and triterpenoids.

\subsection{Experimental Design}

Screening of Borassus flabellifer flower ethanol extract for anti-diabetic effect was screened in rats by conducting Glucose Tolerance Test (GTT) study and evaluating their effects (Single dose and Multidose treatment study) on blood glucose level, serum lipid profiles and histopathology of pancreas in alloxan induced diabetic rats.

\subsection{Acute Toxicity Study}

Determination of $\mathrm{LD}_{50}$ was done as per OECD-423 guidelines for fixing the therapeutic dose for screening purpose. The animals were fasted overnight prior to the experiment and maintained under standard conditions. $2000 \mathrm{mg} / \mathrm{kg}$ b. w. was taken as starting dose; $\mathrm{LD}_{50}$ was determined and $1 / 10$ of $\mathrm{LD}_{50}$ was taken as therapeutic dose for anti-diabetic activity i. e. $200 \mathrm{mg} / \mathrm{kg} \mathrm{b.} \mathrm{w.}{ }^{13}$.

\subsection{Oral Glucose Tolerance Test (OGTT)}

Fasting blood glucose level of each rat was determined at zero time after overnight fasting with free access to water only. Rats were divided into three groups containing six rats in each. Group-I (Control group) received $1 \mathrm{ml}$ of $1 \%$ gum acacia suspension, GroupII (standard drug) received Glibenclamide $(2.5 \mathrm{mg} /$ kg- standard) and Group-III received Borassus flabellifer flower ethanol extract $(200 \mathrm{mg} / \mathrm{kg})$, by oral route using an orogastric tube respectively. Glucose $(2 \mathrm{gm} / \mathrm{kg})$ was orally administered $30 \mathrm{~min}$ after the administration of gum acacia, glibenclamide and extract. Blood samples were collected from the tail vein under ether anesthesia just prior to and 30, 60, 120 and 240 min after glucose loading. Glucose levels were estimated using glucoseoxidase-peroxidase reactive strips and a glucometer (Sugar-check, Wockhardt Ltd, Mumbai, India) ${ }^{14}$.

\subsection{Effect of Borassus flabellifer Flower Ethanol Extract on Blood Glucose Levels in Alloxan Induced Diabetic Rats [Single Dose (Acute) Treatment]}

A single intraperitoneal injection of $120 \mathrm{mg} / \mathrm{kg}$ of alloxan monohydrate was employed to induce diabetes. After $72 \mathrm{hr}$, animals with blood glucose levels higher than $250 \mathrm{mg} / \mathrm{dl}$ were considered diabetic and were included in the study. Animals were divided into four groups containing six rats each. Group I: Normal control rats administered $1 \mathrm{ml}$ of $1 \%$ gum acacia suspension; Group II: Diabetic control rats administered $1 \mathrm{ml}$ of $1 \%$ gum acacia suspension; Group III: Diabetic rats administered Glibenclamide (2.5 mg/kg) and Group IV: Diabetic rats administered Borassus flabellifer flower ethanol extract $(200 \mathrm{mg} / \mathrm{kg})$ orally. Blood samples were collected from the tail vein prior to and at 30, 60, 120, 240, and 360 min intervals after the administration of the extract and blood glucose levels were estimated ${ }^{15}$.

\subsection{Effect of Borassus flabellifer Flower Ethanol Extract on Blood Glucose Levels and Serum Lipid Profiles in Alloxan Induced Diabetic Rats [Multi Dose (Sub Acute) Treatment]}

Diabetes was induced in overnight fasted rats by a single intraperitoneal injection of $120 \mathrm{mg} / \mathrm{kg}$ of alloxan monohydrate. After $72 \mathrm{hr}$, animals with blood glucose levels higher than $250 \mathrm{mg} / \mathrm{dl}$ were considered diabetic and were included in the study. Animals were divided into four groups comprising of six rats each. Group I: Normal control rats administered $1 \mathrm{ml}$ of $1 \%$ gum acacia suspension; Group II: Diabetic control rats administered $1 \mathrm{ml}$ of $1 \%$ gum acacia suspension; Group III: Diabetic 
rats administered Glibenclamide $(2.5 \mathrm{mg} / \mathrm{kg})$ and Group IV: Diabetic rats administered Borassus flabellifer flowers ethanol extract $(200 \mathrm{mg} / \mathrm{kg})$ orally. These rats were given the same doses of the extract once daily for 15 days in this study. Blood samples were collected from the tail vein of nonfasted rats on days $0,5,10$ and 15 of extract administration and blood glucose levels were estimated using glucometer. Serum lipid profiles on day 15 were measured by semi autoanalyzer ${ }^{15}$.

\subsection{Histopathological Studies}

Pancreatic tissues from rats of all groups of multi dose (sub-acute) treatment were subjected to histopathological studies. The animals were sacrificed; the whole pancreas from each animal was removed and stored in $10 \%$ formalin solution. Sections of $5 \mu \mathrm{m}$ thickness were cut and stained by Hematoxylin and Eosin (H and $\mathrm{E}$ ) for histological examination ${ }^{16}$.

\subsection{In-vitro Antioxidant -DPPH Free Radical Scavenging Activity}

The free radical scavenging activity of Borassus flabellifer flower ethanol extract was measured by 1, 1-diphenyl-2picryl-hydrazyl (DPPH). For DPPH assay, the method of Blois was adopted. The capacity of Borassus flabellifer flowers ethanol extract at different concentration was allowed to react with DPPH. Thirty minutes later the capacity to scavenge the lipid-soluble DPPH radical was determined by measuring the absorbance at 517 $\mathrm{nm}$. The percentage inhibition was calculated for each concentration relative to a blank absorbance using the UV spectrophotometer. The DPPH scavenging capacity of the extracts is compared with that of BHT (Butylated hydroxytolune). Lower absorbance of the reaction mixture indicates higher free radical scavenging activity. All determinations are carried out in triplicate. $\mathrm{IC}_{50}$ value in the tested compound is, the concentration required to scavenge 50\% DPPH free radical. Percentage inhibition was calculated as DPPH radical scavenging activity.

DPPH radical Scavenging effect $(\%)=$

((Abs control-Abs sample))

$$
\text { ((Abs control)) X } 100
$$

Where, Abs control is the absorbance of initial conc. of DPPH radical;
Abs sample is the absorbance of DPPH radical + sample Extract /standard

\subsection{Statistical Analysis}

Values are recorded as mean \pm S.E.M. Statistical difference between treatments and the controls were tested by one-way analysis of variance (ANOVA), followed by Dunnett's multiple comparison test using the Graph pad Prism-5. A difference in the mean values of $\mathrm{P}<0.05$ was considered to be statistically significant.

\section{Results}

\subsection{Acute Toxicity Study}

Even at the highest dose $(2000 \mathrm{mg} / \mathrm{kg})$, acute toxicity study revealed no mortality or any toxic reactions with oral administration of extract. It was considered safe to use for the screening which was carried out at 1/10 doses of $\mathrm{LD}_{50} \cdot{ }^{14}$.

\subsection{Oral Glucose Tolerance Test (OGTT)}

Ethanol extract of flowers of Borassus flabellifer significantly $(\mathrm{P}<0.05)$ improved the glucose tolerance up to $4 \mathrm{hrs}$ (Table 1 and Fig. 1). Ethanol extract of Borassus flabellifer showing approximately 18, 22 and 14 $\%$ reduction in blood glucose level from control values at the $1 \mathrm{hr}, 2 \mathrm{hr}$ and $4 \mathrm{hr}$ respectively. The Glibenclamide also improved the glucose tolerance test up to $4 \mathrm{hrs}$.

\subsection{Effect of Borassus flabellifer Flowers Ethanol Extract on Blood Glucose Levels in Alloxan Induced Diabetic Rats [Single Dose (Acute) Treatment]}

Administration of Borassus flabellifer flower ethanol extract was found to reduce the blood glucose level significantly $(\mathrm{P}<0.05)$ in alloxan induced diabetic rats. The anti-hyperglycemic effect from $1 \mathrm{hr}$ after oral administration lasts up to $6 \mathrm{hrs}$ when compared with normal rats and diabetic control rats. Blood glucose lowering potential percentage of Borassus flabellifer was $15 \%$ and $20 \%$ at the end of $4 \mathrm{hr}$ and $6 \mathrm{hr}$, while the standard drug Glibenclamide $(2.5 \mathrm{mg} / \mathrm{kg})$ caused $16 \%$ and $19 \%$ reduction of blood glucose at the same time interval when compared with diabetic control rats (Table 2 and Fig. 2). 
Table 1: Effect of Borassus flabellifer flower ethanol extract on the blood glucose levels in glucose loaded rats

\begin{tabular}{|c|c|c|c|c|c|c|}
\hline \multirow{2}{*}{$\begin{array}{l}\text { Exp. Group } \\
(n=6)\end{array}$} & \multirow[t]{2}{*}{ Treatment } & \multicolumn{5}{|c|}{ Blood glucose concentration (mg/dl) (mean \pm S.E.M.) } \\
\hline & & In fasting & $30 \mathrm{~min}$ & $60 \mathrm{~min}$ & $120 \mathrm{~min}$ & $240 \mathrm{~min}$ \\
\hline I & $\begin{array}{l}\text { Normal control } \\
\text { (1\% Gum Acacia) }\end{array}$ & $92.8 \pm 2.9$ & $161.6 \pm 4.1$ & $162.7 \pm 2.6$ & $161.2 \pm 3.5$ & $132.3 \pm 3.2$ \\
\hline II & $\begin{array}{c}\text { Glibenclamide } \\
(2.5 \mathrm{mg} / \mathrm{kg})\end{array}$ & $96.0 \pm 2.4$ & $143.0 \pm 2.4$ * & $145.8 \pm 1.2 *$ & $137.0 \pm 2.2 *$ & $98.9 \pm 1.2 *$ \\
\hline III & $\begin{array}{l}\text { Borassus flabellifer } \\
\text { flower ethanol } \\
\text { extract }(200 \mathrm{mg} / \mathrm{kg})\end{array}$ & $97.6 \pm 3.9$ & $131.0 \pm 3.0 *$ & $132.7 \pm 3.2$ * & $125.7 \pm 2.9 *$ & $114.0 \pm 1.4$ * \\
\hline
\end{tabular}

Significant, compared to control: ${ }^{*} P<0.01$

$\mathrm{n}=$ no of animals in each group

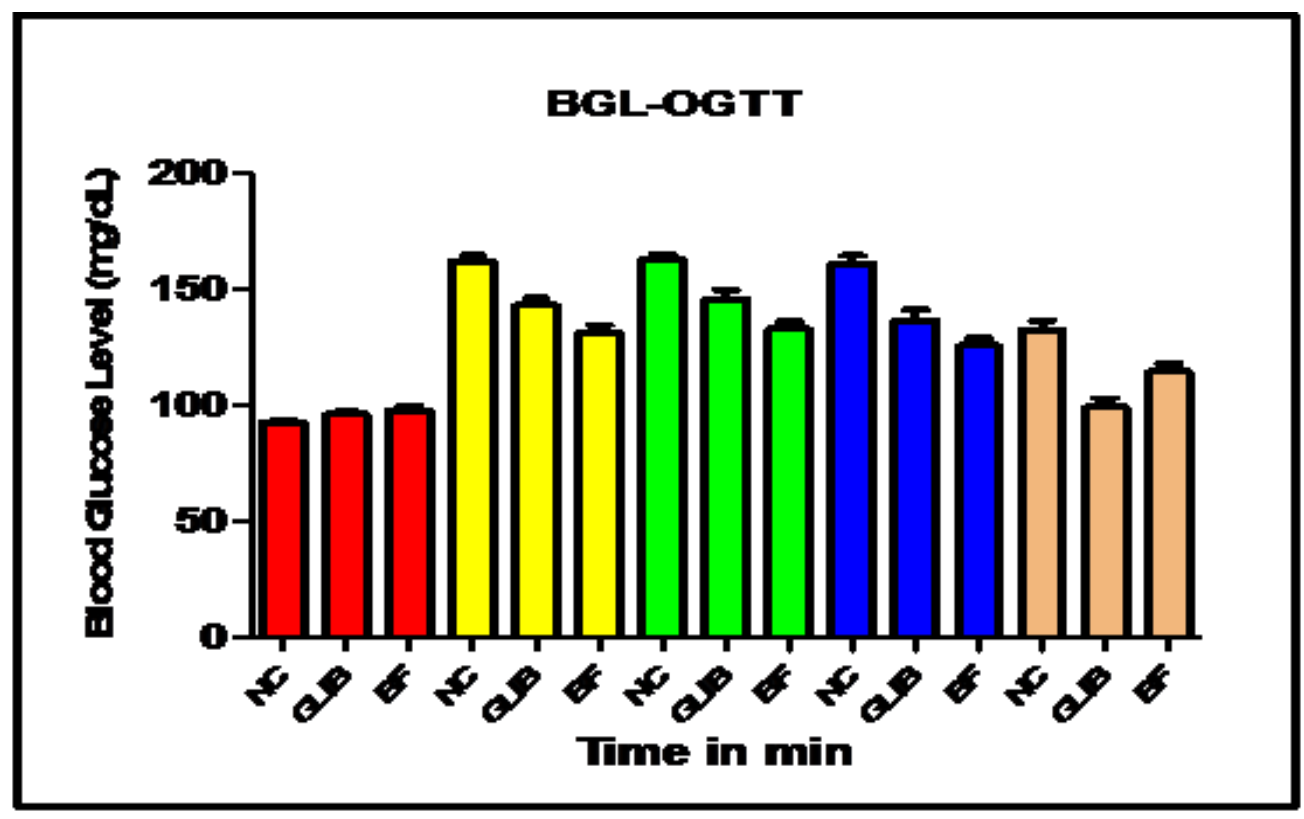

Fig. 1. Effect of Borassus flabellifer flower ethanol extract on the blood glucose concentration in glucose loaded rats.

Table 2: Effect of Borassus flabellifer flower ethanol extract on the blood glucose levels in diabetic rats (Single dose treatment /acute study)

\begin{tabular}{|c|c|c|c|c|c|c|c|}
\hline \multirow{2}{*}{$\begin{array}{l}\text { Exp. Group } \\
(n=6)\end{array}$} & \multirow[t]{2}{*}{ Treatment } & \multicolumn{6}{|c|}{ Blood glucose concentration (mg/dl) (mean \pm S.E.M.) } \\
\hline & & 0 hour & $30 \mathrm{~min}$ & $60 \mathrm{~min}$ & $120 \mathrm{~min}$ & $240 \mathrm{~min}$ & $360 \mathrm{~min}$ \\
\hline I & $\begin{array}{l}\text { Normal control } \\
\text { (1\% gum acacia) }\end{array}$ & $87.2 \pm 2.4$ & $88.4 \pm 2.1$ \#\# & $90.50 \pm 2.3^{\# \#}$ & $90.86 \pm 1.8^{\# \#}$ & $94.4 \pm 2.2^{\# \#}$ & $95.76 \pm 3.1^{\# \#}$ \\
\hline II & Diabetic control & $288.8 \pm 5.0$ & $296.4 \pm 5.1^{*}$ & $297.1 \pm 5.2^{*}$ & $291.3 \pm 4.1^{*}$ & $293.5 \pm 3.5^{*}$ & $294.0 \pm 4.1^{*}$ \\
\hline III & $\begin{array}{l}\text { Glibenclamide } \\
(2.5 \mathrm{mg} / \mathrm{kg})\end{array}$ & $298.3 \pm 6.2$ & $285.1 \pm 7.0^{*}$ & $271.3 \pm 9.3^{*}$ & $259.0 \pm 11.9 * \#$ & $253.8 \pm 12.1^{* \# \#}$ & 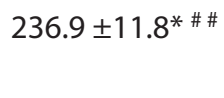 \\
\hline IV & $\begin{array}{l}\text { Borassus flabellifer } \\
\text { flower ethanol } \\
\text { extract }(200 \mathrm{mg} / \mathrm{kg})\end{array}$ & $290.5 \pm 6.7$ & $278.2 \pm 6.1^{*} \#$ & $269.6 \pm 4.2^{* \# \#}$ & $258.2 \pm 5.4^{*}$ & $250.8 \pm 5.1^{* \# \# ~}$ & $234.2 \pm 6.2^{* \# \#}$ \\
\hline
\end{tabular}

${ }^{*} P<0.01$ Significant, compared to normal, ${ }^{\#} P<0.05 \&{ }^{\#} P<0.01$ Significant, compared to diabetic control.

$\mathrm{n}=$ no of animals in each group 


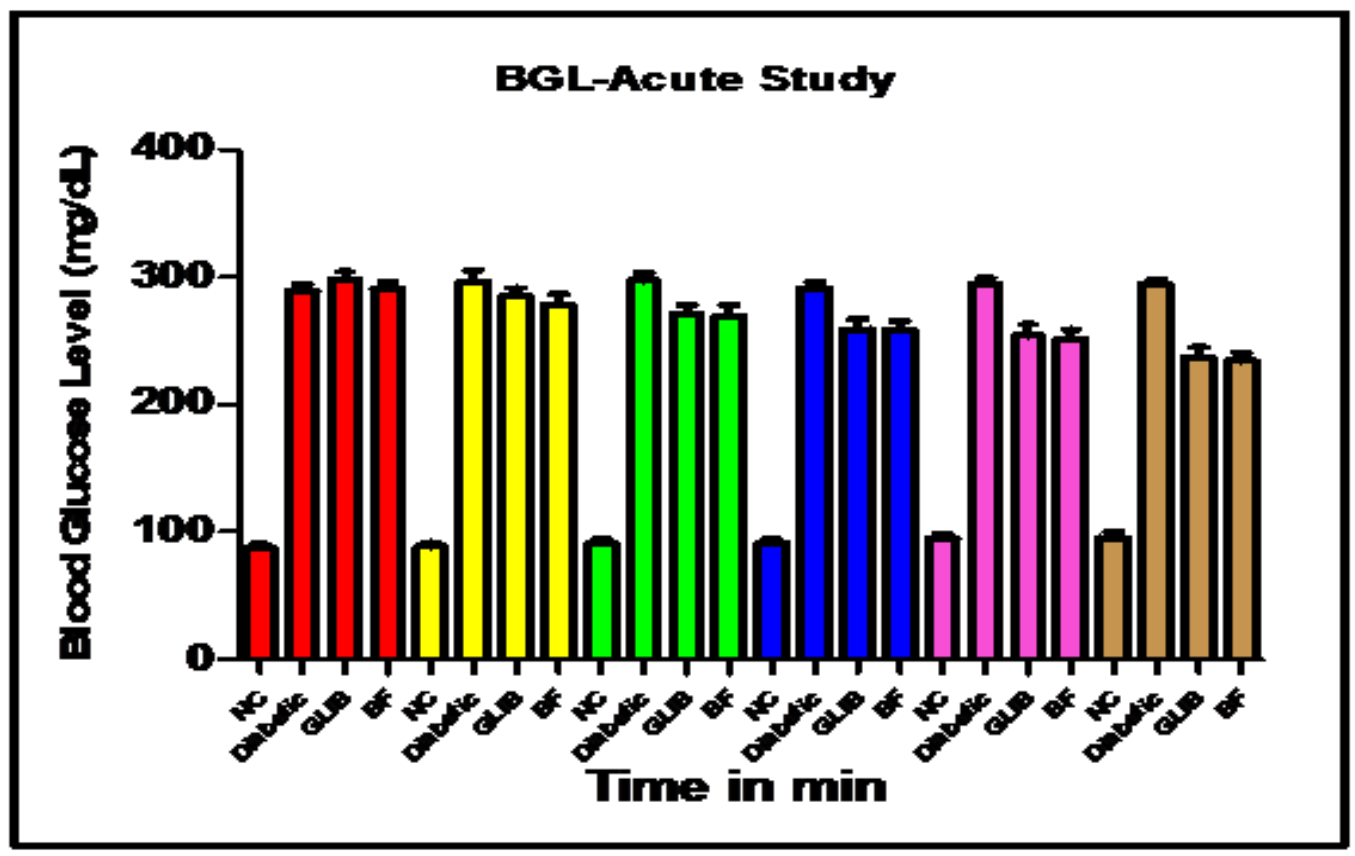

Fig. 2. Effect of Borassus flabellifer flower ethanol extract on the blood glucose concentration in diabetic rats (Single dose treatment / acute study).

\subsection{Effect of Borassus flabellifer Flower Ethanol Extract on Blood Glucose in Alloxan Induced Diabetic Rats [Multi Dose (Sub-Acute) Treatment]}

In sub-acute treatment, Borassus flabellifer flower ethanol extract was administered for consecutive 15 days. After administration of test samples the blood glucose level of each animal was monitored on $0^{\text {th }}, 5^{\text {th }}, 10^{\text {th }}$ and $15^{\text {th }}$ day. The initial anti-diabetic activity was observed on 5th day and continued to increase in all groups during the experimental period (Table 3 and Fig. 3). During the Multidose treatment, administration of ethanolic extract $(200 \mathrm{mg} / \mathrm{kg} /$ day $)$ causes a significant decrease of $21 \%, 32 \%$ and $35 \%$ in blood glucose levels on $5^{\text {th }}, 10^{\text {th }}$ and $15^{\text {th }}$ day, respectively, when compared with diabetic control group.

\subsection{Effect of Borassus flabellifer Flower Ethanol Extract on Serum Lipid Profiles in Alloxan Induced Diabetic Rats [Multi Dose (Sub-Acute) Treatment]}

Hyperlipidemia is a common complication of alloxaninduced diabetes mellitus in experimental animals. Serum lipid profiles study on day 15 , reveals significant changes in levels of serum cholesterol, triglyceride, LDL, VLDL, and HDL. When compared to normal control (Group I), serum Total Cholesterol (TC), Triglyceride (TG), Low Density Lipoprotein (LDL) and Very LowDensity Lipoprotein (VLDL) increased and High Density Lipoprotein Cholesterol (HDL) decreased diabetic group animals (Group II). Treatment with ethanolic extract of flower of Borassus flabellifer $(200 \mathrm{mg} / \mathrm{kg}$ ) and Glibenclamide in hyperlipidemic rats for 15 consecutive days, there was a significant decrease in serum lipids (TC, TG, LDL and VLDL), while there was an marked increase in HDL (Table 4).

\subsection{Histopathological Studies}

Histopathological examination of pancreas showed (Fig. 4) comparable regeneration of Islets of Langerhans and $\beta$ cells by ethanolic extracts of Borassus flabellifer flower and Glibenclamide, which were earlier, under necroses due to alloxan. Fig. 5 (A-D) depicts the islets of pancreas of rats in different groups. Photomicrographs (A) of the normal control animals (Group I) showed normal acini and normal cellular population of the islets of langerhans. In diabetic animals (Group II) there was extensive damage of the islets of langerhans and they appeared to be irregular (B). Treatment with 
Table 3: Effect of Borassus flabellifer flower ethanol extract on the blood glucose levels in diabetic rats (Multi-dose treatment /sub acute study)

\begin{tabular}{|c|c|c|c|c|c|}
\hline \multirow{2}{*}{$\begin{array}{l}\text { Exp. Group } \\
(n=6)\end{array}$} & \multirow[t]{2}{*}{ Treatment } & \multicolumn{4}{|c|}{ Fasting blood glucose concentration (mg/dl) (mean \pm S.E.M.) } \\
\hline & & $0^{\text {th }}$ Day & $5^{\text {th }}$ Day & $10^{\text {th }}$ Day & $15^{\text {th }}$ Day \\
\hline I & $\begin{array}{l}\text { Normal control } \\
\text { (1\% gum acacia) }\end{array}$ & $87.35 \pm 2.2$ & $87.75 \pm 2.8^{\# \#}$ & $87.35 \pm 2.3 \# \#$ & $88.35 \pm 1.8^{\# \#}$ \\
\hline II & Diabetic control & $288.2 \pm 5.2$ & $277.6 \pm 7.1^{* *}$ & $268.3 \pm 4.2^{* *}$ & $256.8 \pm 4.1^{* *}$ \\
\hline III & $\begin{array}{l}\text { Glibenclamide } \\
(2.5 \mathrm{mg} / \mathrm{kg})\end{array}$ & $300.3 \pm 6.9$ & $222.3 \pm 12.3^{* * \# \#}$ & $190.3 \pm 12.8^{* * \# \#}$ & $172.3 \pm 14.3^{* * \# \#}$ \\
\hline IV & $\begin{array}{c}\text { Borassus flabellifer } \\
\text { flower ethanol extract } \\
(200 \mathrm{mg} / \mathrm{kg})\end{array}$ & $292.3 \pm 6.0$ & $218.0 \pm 5.2^{* * \#}$ & $183.5 \pm 9.4^{* * \# \#}$ & $166.5 \pm 7.3^{* \# \#}$ \\
\hline
\end{tabular}

${ }^{*} P<0.05 \&{ }^{* *} P<0.01$ Significant, compared to normal, ${ }^{\#} P<0.05 \&{ }^{\#} P<0.01$ Significant, compared to diabetic control. $\mathrm{n}=$ no of animals in each group

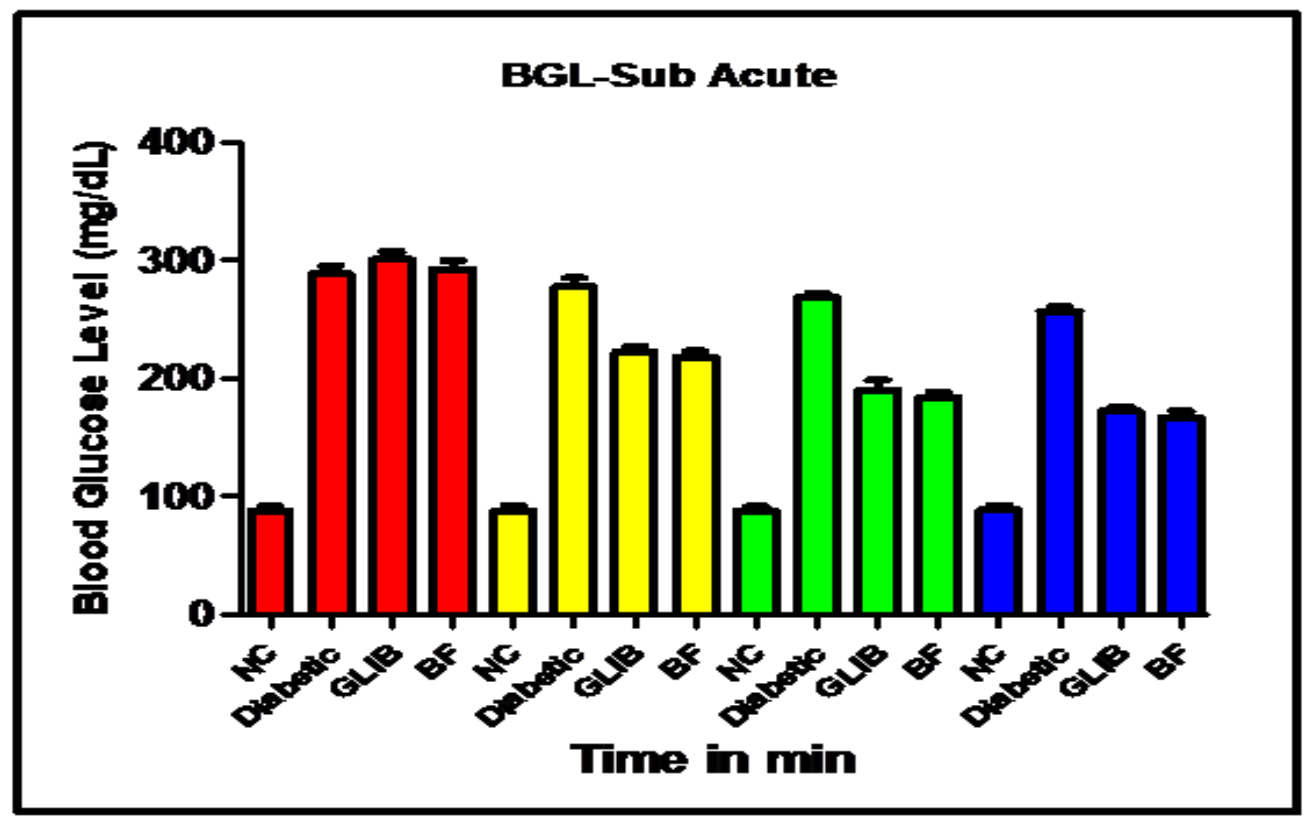

Fig. 3. Effect of Borassus flabellifer flower ethanol extract on the blood glucose levels in diabetic rats (Multi dose treatment /sub acute study).

Table 4: Effect of Borassus flabellifer flower ethanol extract on the Serum lipid profiles in diabetic rats after 15 days of treatment

\begin{tabular}{|c|c|c|c|c|c|c|}
\hline $\begin{array}{l}\text { Exp. Group } \\
(n=6)\end{array}$ & Treatment & TGL mg/dl & $\mathrm{HDL} \mathrm{mg} / \mathrm{dl}$ & VLDL mg/dl & LDL mg/dl & $\begin{array}{c}\text { Total Cholesterol } \\
\mathrm{mg} / \mathrm{dl}\end{array}$ \\
\hline I & Normal control (1\% gum acacia) & $76.83 \pm 2.0$ & $50.3 \pm 2.1$ & $21 \pm 0.9$ & $18 \pm 1.2$ & $53.3 \pm 2.5$ \\
\hline ॥ & Diabetic control & $123 \pm 2.7$ & $35.2 \pm 0.9$ & $38.3 \pm 1.7$ & $39.7 \pm 1.9$ & $88.2 \pm 2.9$ \\
\hline III & Glibenclamide (2.5 mg/kg) & $87 \pm 2.3$ & $47 \pm 1.8$ & $22.5 \pm 1.2$ & $21.2 \pm 2.2$ & $59.5 \pm 1.7$ \\
\hline IV & $\begin{array}{c}\text { Borassus flabellifer flower ethanol } \\
\text { extract }(200 \mathrm{mg} / \mathrm{kg})\end{array}$ & $98.3 \pm 2.3$ & $41 \pm 1.9$ & $26 \pm 1.8$ & $28.3 \pm 1.2$ & $75.5 \pm 2.2$ \\
\hline
\end{tabular}

${ }^{*} P<0.05 \&{ }^{* *} P<0.01$ Significant, compared to diabetic control.

$\mathrm{n}=$ no of animals in each group 


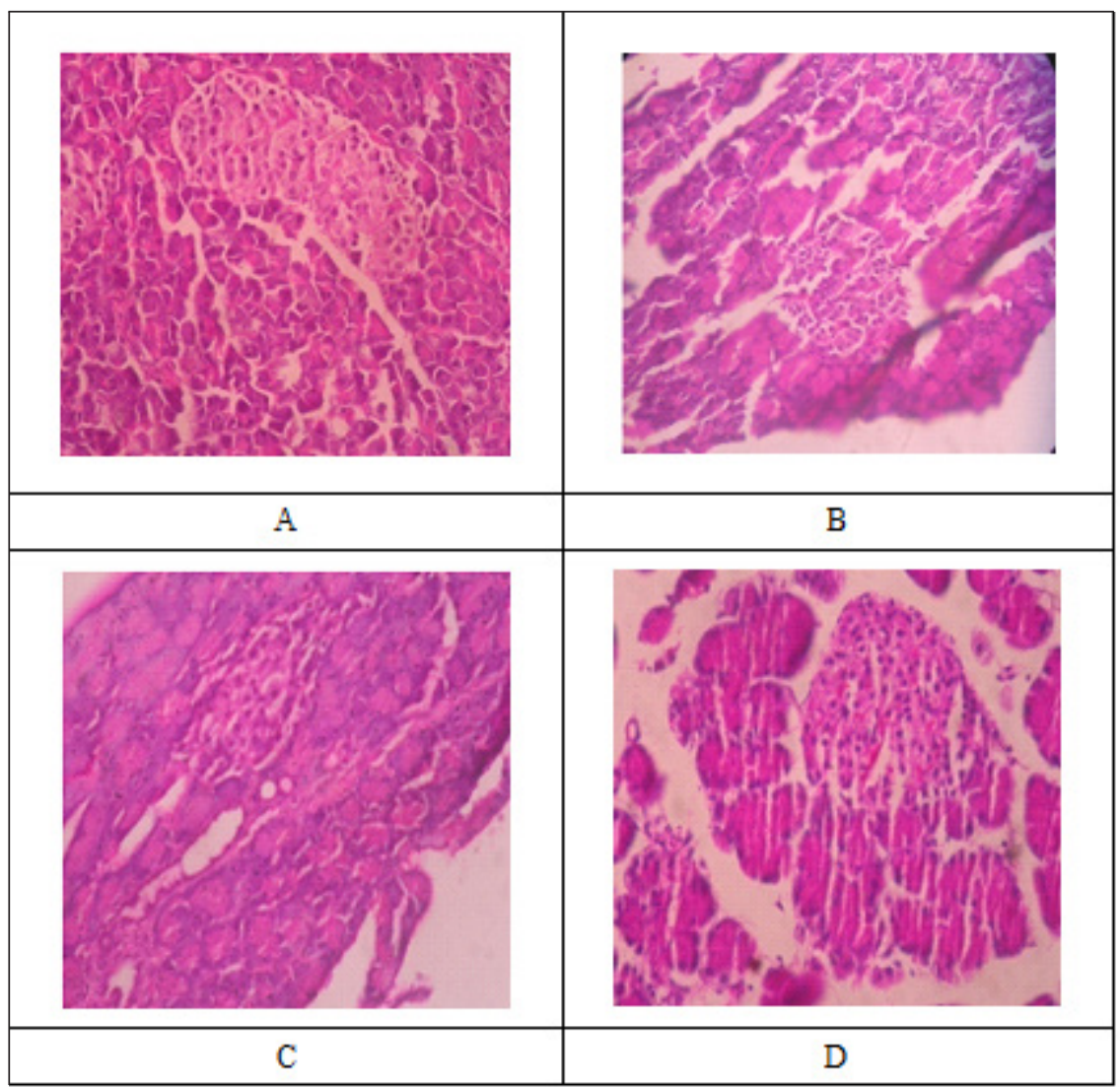

Fig. 4. Histology of rat pancreas after 15 days of treatment with ethanol extract of Borassus flabellifer flowers.

A. Normal control rats showed normal pancreatic tissue, while

B. Alloxan-induced diabetic rats had severe decrease in number of islets of Langerhans cells and $\beta$ cells

C. Pancreatic tissue of diabetic rats treated with Glibenclamide $(2.5 \mathrm{mg} / \mathrm{kg})$ and

D. Ethanol extract of Borassusflabelliferflowers $(200 \mathrm{mg} / \mathrm{kg})$ showed partial restoration of normal cellular population and size of islet cells

glibenclamide showed moderate expansion of cellular population and size of islet cells (C). However, ethanol extract $(200 \mathrm{mg} / \mathrm{kg})$ treated-diabetic rats showed partial restoration of normal cellular population and size of islet cells (D).

\subsection{In-vitro Antioxidant (DPPH Free Radical Scavenging) Activity}

Several concentrations ranging from $10-1000 \mu \mathrm{g} / \mathrm{ml}$ of ethanol extract of flowers of Borassus flabellifer tested for their antioxidant activity by DPPH model. It has been observed that free radicals were scavenged in a concentration dependent manner in this DPPH assay (Table 5) with an $\mathrm{IC}_{50}$ value of $460 \mu \mathrm{g} / \mathrm{ml}$ when compared with Standard BHT (Butylated hydroxytolune) IC $_{50}$ value of $419 \mu \mathrm{g} / \mathrm{ml}$.

\section{Discussion}

For a diabetic person controlling the blood sugar level is of prime concern. As age increases, the effect of oral hypoglycemic drugs to keep the sugar levels in normal range decreases leading to complications. Medicinal plants or herbal dugs are recommended and used in several countries for the management of DM. These are believed to be non-toxic; economic with better patient compliance. Oxidative stress is one of the contributory factors in the pathogenesis of diabetes. Diabetes, by itself, increases the production of tissue damaging Reactive Oxygen Species (ROS) by glucose auto-oxidation and / or no enzymatic protein glycosylation ${ }^{2}$ Complications of diabetes seem to be mediated by oxidative stress. Hyperglycemia is one of the main causes of oxidative stress in type-II diabetes. In hyperglycemia, increased 


\begin{tabular}{lcc} 
Table 5: & $\begin{array}{c}\text { DPPH scavenging activity of ethanol extract of Borassus } \\
\text { flabellifer flower }\end{array}$ \\
\hline $\begin{array}{l}\text { Concentration } \\
(\mu \mathrm{g} / \mathrm{ml})\end{array}$ & \multicolumn{2}{c}{ DPPH scavenging (\% inhibition) } \\
\cline { 2 - 3 } & $\begin{array}{c}\text { Borassus flabellifer } \\
\text { Flower ethanolic extract }\end{array}$ & $\begin{array}{c}\text { BHT } \\
\text { (Butylated hydroxytolune) }\end{array}$ \\
\hline 10 & $3.19 \%$ & 20.08 \\
50 & $18.76 \%$ & 38.17 \\
100 & $22.95 \%$ & 59.64 \\
250 & $38.52 \%$ & 90.26 \\
500 & $54.29 \%$ & 97.22 \\
1000 & $64.47 \%$ & 95.23 \\
$\mathrm{IC}_{50}$ & $460 \mu \mathrm{g} / \mathrm{mL}$ & $419 \mu \mathrm{g} / \mathrm{mL}$ \\
\hline
\end{tabular}

blood level promotes protein glycation and Advanced Glycation End Products (AGEs). Reactive oxygen species (ROS) are formed in this process and trigger tissue damage. Recently, the progressive deterioration of $\beta$ cell function in type-II diabetes has been accounted for oxidative stress-induced tissue damage ${ }^{17}$.

Overall results show that ethanol extract of Borassus flabellifer flower possesses marked anti-hyperglycemic activity by improvement of glucose tolerance test and by lowering the blood glucose levels in alloxan-induced diabetic rats in single dose (acute) and multi dose (sub-acute) treatment study. The ethanolic extract and Glibenclamide exhibited remarkable blood glucose lowering effect in glucose tolerancetest. The hypoglycemic effect comparable to Glibenclamide suggested that the active fractions may act by regenerating the $\beta$ cells in alloxan-induced diabetes ${ }^{18}$. Alloxan causes diabetes through its ability to destroy the insulin producing $\beta$ cells of the pancreas. In vitro studies have shown that alloxan is selectively toxic to the pancreatic $\beta$ cells, causing cell necrosis. The cytotoxic action of alloxan is mediated by reactive oxygen species, with a simultaneous massive increase in cytosolic calcium concentration, leading to a rapid destruction of $\beta$ cells $^{19}$.

In the present study, damage of pancreas was observed in alloxan-treated diabetic rats (Fig. 4B). The glibenclamide-treated group showed regeneration of $\beta$ cells (Fig. 4C). The comparable regeneration was also shown by ethanol extracts of Borassus flabellifer flowers (Fig.4D). Photomicrographs reinforce healingof pancreas by the ethanolic extracts as a plausible mechanism of their anti-diabetic activity. The anti-diabetic activity of extract may be due to the presence of flavonoids and tri-terpenoids. It is reported that flavonoids constitute the active biological principles of most medicinal plants with hypoglycemic and anti-diabetic properties ${ }^{20}$.

After Borassus flabellifer treatment, blood glucose, TC, TG, LDL and VLDL of all tested rats were significantly decreased and at the same time HDL was increased. This provided evidence in favor of the view that Borassus flabellifer could play an important role in treating diabetic/hyperlipidemic patients. Many current oral hypoglycemic or hypolipidemic agents are synthetic drugs with certain adverse side effects ${ }^{21}$. Our study reveals the potential of Borassus flabellifer for use as a natural oral agent with both hypoglycemic and hypolipidemic effects.

For determining the antioxidant activity of several natural compounds, DPPH (1, 1-diphenyl -2-picryl hydrazyl) radical was widely used. Plants constitutes a rich source of antioxidants, which include tochopherols, Vitamin C, phenolic compounds, carotenoids, flavonoids, terpenoids, anthraquinones, steroids, strychnine and eugenol alkaloids ${ }^{22,23}$. From data obtained, it may be postulated that ethanolic extract of Borassus flabellifer flower significantly $\left(\mathrm{IC}_{50} 460 \mu \mathrm{g} / \mathrm{mL}\right.$ ) reduces the radical to corresponding hydrazine (BHT - $\mathrm{IC}_{50} 419 \mu \mathrm{g} / \mathrm{mL}$ ), when it reacts with hydrogen donors in antioxidant principles, thus it can be concluded that Borassus flabellifer flower ethanol extract has potent in-vitro antioxidant potential which is attributed due to the presence of flavonoids and triterpenoids like constituents present.

In certain chronic disease states, it is evident that poor free radical scavenging effect as well as increased 
production of ROS plays a crucial role. The chemical changes occurring in almost all cellular components are believed to be due to hyperactivity of free radicals, resulting in lipid peroxidation. The development of diabetic complications is attributed to the elevated production of free radicals and oxidative stress ${ }^{24}$. The oxidative stress is at significantly elevated level in diabetic patients as compared to normal population. With the quantum of evidence and data reported, it can be convincingly put forth the correlation between the damaging consequences of oxidative stress and pathophysiology of diabetes ${ }^{25}$. Reduced insulin synthesis and decrease in $\mathrm{b}$ cell mass are believed to be causative factors for development of diabetes. In a study, the antioxidants are found to regulate glycemic control by protecting beta cell functions. Also it was observed that there was no change in glucose tolerance in non diabetic animals. From this it can be inferred that, antioxidants increases the $b$ cell mass and preserves insulin content ${ }^{26}$ a Lipoic acid, a non enzymatic antioxidant produced endogenously, protects the insulin receptors from harmful effects of oxidative stress, there by improves glucose uptake through insulin apparently by modulating insulin sensitivity.

It is conceivable that antioxidant/ free radical scavenging activity of Borassus flabellifer flowers ethanol extract is one of the mechanism associated with antidiabetic effect. The other mechanism is regeneration and moderate expansion of cellular population and size of islet of Langerhans and $\beta$ cells by ethanol extracts of Borassus flabellifer flowers. However, ethanol extract (200 $\mathrm{mg} / \mathrm{kg}$ ) treated-diabetic rats showed partial restoration of normal cellular population and size of islet cells. These results seem to confirm the alleged anti-diabetic activity by the traditional medicine. However the extract should further be subjected to bioactivity-guided drug discovery to isolate the lead compound responsible for anti-diabetic activity and possible mechanisms(s) of action.

\section{Conflicts of Interest}

There are no conflicts of interest.

\section{Acknowledgement}

The authors are thankful to Principal, K.L.E.University, College of Pharmacy, Belagavi, India; for providing facilities to carry out this research work. The authors are grateful Prof. R. S. Goudar, Dept. of Botany, KLES's R. L. Science Institute, Belagavi, (Karnataka) India for authenticating the plant material.

\section{References}

1. Mishra A, Garg GP. Anti-diabetic activity of fruit pulp of Cordia dichotoma in alloxan induced diabetic rats. Indian Journal of Pharmaceutical Sciences and Research. 2011; 2(9): 2314-9.

2. Gokce G, Haznedaroglu MZ. Evaluation of anti-diabetic, antioxidant and vasoprotective effects of Posidonia oceanica extract. Journal of Ethnopharmacology. 2008; 115:122-30.

3. Guo Z, Su W, Allen S, Pang H, Daugherty A, Smart E, Gong MC. COX-2 up-regulation and vascular smooth muscle contractile hyper reactivity in spontaneous diabetic $d b / d b$ mice. Cardiovascular Research. 2005; 67:723-35.

4. Mazire C, Auclair M, Rose-Robert F, Leflon P, Mazire JC. Glucose-enriched medium enhances cell-mediated low density lipoprotein peroxidation. FEBS Letters. 1995; 363:277-9.

5. Sinha D, Dwivedi C, Dewangan M, Yadav R, Rao S, Chandrakar K, Singh S, Roy A. Anti-diabetic potential of herbal plants and polyherbal formulation. International Journal of Phytotherapy Research. 2014; 4(3):28-49.

6. Shibly A, Zohora F, Islam Md S, Islam Md. R. A comprehensive review on ethno pharmacological anti-diabetic potential of traditional ayurvedic plants of Bangladesh. Journal of Pharmacognosy and Phytochemistry. 2015; 4(1):107-12.

7. Sudhakar K, Vijaya l, Gowri S, Matsyagiria L, Shankar M, Sandhyab S. Antioxidant activity of methanolic extracts of female Borassus flabellifer leaves and roots. Der Pharmacia Sinica. 2011; 2(3):193-9.

8. Nagendra S, Jyothi P, Rajeswara R, Surya K, Kaladhar D, Sai D, Parvathi T, Gangadhar.H, Siva Kumar K,Govinda R. In-vitro dose dependent study on antihuman pathogenic bacterial and free radical scavenging activities of methanolic seed coat extract of Borassus flabellifer L. Asian Journal of Pharmaceutical and Clinical Research. 2012; 5(2):83-6.

9. Sandhya S, Sudhakar K, David B, Rao K. Pharmacognostical standardization of Borassus flabellifer root. Annals of Biological Research. 2010; 1(4):85-94.

10. Duddukuri G, Sastry Y, Kaladhar D, Rao K, Chaitanya K. Antibacterial activity of methanolic seed coat 
extracts of Borassus flabellifer L. International Journal of Pharmaceutical Science and Research. 2011; 2(9):2435-8.

11. Paschapur M, Patil M, Ravi K, Patil S. Evaluation of antiinflammatory activity of ethanolic extract of Borassus flabellifer L. male flowers (inflorescences) in experimental animals. Journal of Medicinal Plants Research. 2009; 3(2):49-54.

12. Kurian JC, Mutatkar RK, Samraj E. Plants that heal. 1st ed. Pune: Oriental Watchman Publishing House; 1995. p. 83.

13. OECD/OCDE. Acute Oral Toxicity - Acute Toxic Class Method. Oecd Guidel. Test Chem. 2001; 423:1-14.

14. Shirwaikar A, Rajendran K, Barik R. Effect of aqueous bark extract of Garugapinnata Roxb. in streptozotocinnicotinamide induced type-II diabetes mellitus. Journal of Ethnopharmacology. 2006; 107(2):285-90.

15. Nilufer O, Mustafa A, Didem DO, Fatma E, Erdem Y. Invivo assessment of anti-diabetic and antioxidant activities of grapevine leaves (Vitis vinifera) in diabetic rats. Journal of Ethnopharmacology. 2006; 108(2):280-6.

16. Luna LC. Manual of histological screening methods of Armed Forces Institute of Pathology. Ed 125. New York: Mc Graw Hill Book Co; 1960.

17. Kimoto K, Kenji S, Tayako K, Yoshiaki H, Hitoshi I, Hidenori $\mathrm{K}$, et al. Gliclazide protects pancreatic $\beta$-cells from damage by hydrogen peroxide. Biochemical and Biophysical Research Communications. 2003; 303(1):1129.

18. Ghosh S, Suryawanshi SA. Effect of Vinca rosea extracts in treatment of alloxan rats. Indian Journal of Experimental Biology. 2001; 39(8):748-59.

19. Sharma S, Chaturvedi M, Edwin E, Shukla S, Sagrawat $\mathrm{H}$. Evaluation of the phytochemicals and anti-diabetic activity of Ficus bengalensis. International Journal of Diabetes in Developing Countries. 2007; 27(2):56-9.

20. Wollenweber LE, Cody V, Middleton EJ, Harborne JB, Beretz A. Plant Flavonoids in biology and medicine II: Biochemical, cellular and medicinal properties. Progress in Clinical and Biology Research. 1988; 280:1-461.

21. Qiong L, Yizhong C, Jun Y, Mei S, Harold C. Hypoglycemic and hypolipidemic effects and antioxidant activity of fruit extracts from Lycium barbarum. Life Sciences. 2004; 76(2):137-49.

22. Rashmi DR, Subramaniam V. In-vitro antioxidant activity of medicinally important Achyranthes aspera- A preliminary study. Indian drugs. 2006; 44(2):128-32.

23. Tripathi YB, Chaurasia S, Tripathi E, Upadhey A, Dubey GP. Bacopa monniera Linn. as an antioxidant: Mechanism of action. Indian Journal of Experimental Biology. 1996; 34(6):523-6.

24. Roja R, Shekoufeh N, Bagher L, Mohammad A. A review on the role of antioxidants in the management of diabetes and its complications. Biomedicine \& Pharmacotherapy. 2005; 59(7):365-73.

25. Johansen JS, Harris AK, Rychly DJ, Ergul A. Oxidative stress and the use of antioxidants in diabetes: Linking basic science to clinical practice. Cardiovascular Diabetology. 2005; 4(5):1-11.

26. Kaneto H, Kajimoto Y, Miyagawa, J., Matsuoka, T. et. al. Beneficial Effects of Antioxidants in Diabetes: Possible Protection of Pancreatic b-Cells Against Glucose Toxicity. DIABETES, 1999: 48.

27. Bajaj S, Khan A. Antioxidants and diabetes. Ind J Endocrinol Metab. 2012; 16(2):S267-71. doi: $10.4103 / 2230-8210.104057$ 